\title{
Coexistence in Oilseed Rape: Effect of Donor Variety Type and Discarding Field Edges
}

\author{
Maren Langhof ${ }^{1} \&$ Gerhard Rühl $^{1}$ \\ ${ }^{1}$ Institute for Crop and Soil Science, Julius Kühn-Institut (JKI), Federal Research Centre for Cultivated Plants, \\ Braunschweig, Germany \\ Correspondence: Maren Langhof, Institute for Crop and Soil Science, Julius Kühn-Institut (JKI), Federal \\ Research Centre for Cultivated Plants, Bundesallee 50, 38116 Braunschweig, Germany. Tel: 0049-531-596-2308. \\ E-mail: maren.langhof@julius-kuehn.de
}

Received: February 15, $2017 \quad$ Accepted: March 21, $2017 \quad$ Online Published: April 15, 2017

doi:10.5539/jas.v9n5p33

URL: https://doi.org/10.5539/jas.v9n5p33

The research was financed by the German Federal Ministry of Food and Agriculture.

\begin{abstract}
Oilseed rape is one of the most important sources of vegetable oil worldwide. Approximately $24 \%$ of the world's total cultivation area in 2015 was planted with genetically modified (GM) varieties. Until now the cultivation of GM oilseed rape in the EU is not approved since coexistence of GM and non-GM oilseed rape is a matter of significant public concern. One reason is the differing information about pollen-mediated gene flow in this crop species. Therefore, in a 3-year field trial we investigated gene flow using a GM-free marker system consisting of a high erucic acid oilseed rape (HEAR) variety as pollen donor and a low erucic acid oilseed rape (LEAR) variety as pollen recipient. Donor and receptor fields were equally-sized ( 75 by $100 \mathrm{~m}$ or $0.75 \mathrm{ha}$ ) and separated by an isolation distance of $20 \mathrm{~m}$ clover-grass. Two different HEAR varieties, a hybrid variety and a line variety, were compared as pollen donor. Generally, outcrossing rates at $1 \mathrm{~m}$ field depth were significantly highest. A significant decrease in outcrossing was observed in the first donor-facing $20 \mathrm{~m}$ of recipient fields, with no further significant decrease in field depths $>20 \mathrm{~m}$. Outcrossing rates of the total field harvest never exceeded $0.25 \%$. Due to irregular patterns of outcrossing, a separated harvest of the receptor field edge facing the donor plot only marginally reduced the GM content in the total harvest.
\end{abstract}

Keywords: Brassica napus, coexistence, erucic acid, genetically modified, pollen-mediated gene flow, outcrossing

\section{Introduction}

Worldwide, oilseed rape or canola (Brassica napus L.) is the third most important source of vegetable oil, after soya and palm oil (FAO, 2014). Its main production areas in 2014 were Canada (8.1 million ha), China (7.6 million ha), the European Union (EU) (6.7 million ha), and India (6.6 million ha) (Statistics Division Food and Agriculture Organization of the United Nations [FAOSTAT], 2016). Within the EU the most important oilseed rape cultivating countries in 2016 were France (1.5 million ha), Germany (1.3 million ha) and Poland (0.8 million ha) (Eurostat, 2017). Besides its importance as oil for human consumption as well as meal for livestock feed, the production of oilseed rape in the EU increased approximately by one third during the last decade (Eurostat, 2017) especially due to its use for biodiesel production in Europe. In Germany, for example, $60 \%$ of the total oilseed rape production area is dedicated to biodiesel or vegetable oil fuel (German Federal Ministry of Food and Agriculture [BMEL], 2014).

Approximately $24 \%$ of the world's total oilseed rape cultivation area in 2015 was planted with genetically modified (GM) varieties; more than $90 \%$ of this cultivation took place in Canada, other cultivating countries were USA, Australia and Chile (James, 2015). GM oilseed rape varieties grown commercially in these countries were herbicide resistant. There is no authorization for the cultivation of GM oilseed rape in the EU. Coexistence of GM and non-GM crops is a matter of significant public concern in Europe. To give consumers the chance to choose between GM and non-GM crops and food, respectively, mandatory labeling with a threshold set at $0.9 \%$ for the adventitious presence of approved GM material in non-GM food and feed was introduced in 2003 
(European Commission [EC], 2003). To secure the coexistence between GM and non-GM production, crop-specific coexistence measures have been adopted by EU member states. Besides general measures such as separate storage of seeds as well as thorough cleaning of equipment and transport machines, crop species-specific measures have mainly been established for maize, since the insect resistant GM maize MON810 was cultivated since 1998 and currently still is the only GM crop with approval for cultivation in the EU. However, two EU member states (Lithuania and Latvia) already adopted specific coexistence measures for oilseed rape and stipulated an isolation distance of 4,000 m between conventional and GM oilseed rape (EC, 2009), other EU member states so far proposed isolation distances between 35 and $400 \mathrm{~m}$ (Beckie \& Hall, 2015). Large regulated isolation distances arise from skepticism about cultivation of GM oilseed rape in the EU, which is based on the possible spread of transgenes through pollen-mediated gene flow, volunteer emergence, feral oilseed rape plants, seed transfer by machinery or interbreeding with close relatives (Allnutt et al., 2013; Collier \& Mullins, 2012; Gruber \& Claupein, 2007; Hüsken \& Dietz-Pfeilstetter, 2007; Knispel \& McLachlan, 2010). Although oilseed rape is classified as a mainly self-pollinating crop, outcrossing by physical contact, wind and insects has been proven. Under field conditions outcrossing rates of up to $40 \%$ were reported (Becker, Damgaard, \& Karlsson 1992; Lavigne et al., 1998). Due to the visually attractive petals and nectaries, oilseed rape flowers are attractive to many insects, including solitary and social bees, Diptera, Lepidoptera and Coleoptera (Mesa, Howlett, Grant, \& Didham, 2013). Long-distance transport of pollen over several hundreds or even thousands of meters by social bees (particularly honey- and bumblebees) as well as other hymenopteran, dipteran and coleopteran species is a matter of concern for the undesirable spread of GM oilseed rape pollen between arable fields (Chifflet et al., 2011; Ramsey, Thompson, \& Squire, 2003). Oilseed rape is an ambophilous plant, i.e. it can be successfully pollinated by both insects and wind (e.g. Cresswell et al., 2004; Mesquida \& Renard, 1982). Plants release large amounts of pollen into the air (McCartney \& Lacey, 1991; Timmons, O'Brien, Charters, Dubbels, \& Wilkinson, 1995); however transport of airborne pollen is limited due to pollen characteristics. Oilseed rape pollen grains are roughly spherical, relatively large $(32-35 \mu \mathrm{m})$, heavy and sticky and tend to cohere in clumps (Cresswell et al., 2004; Treu \& Emberlin, 2000). Accordingly, airborne pollen concentrations decrease rapidly with increasing distance from the emitter, with the majority of pollen travelling less than $20 \mathrm{~m}$ (Bilsborrow, Evans, Bowman, \& Bland, 1998; Lavigne et al., 1998; Funk, 2006). However, larger dispersal distances in the range of a few kilometers have also been reported (Rieger, Lamond, Preston, Powles, \& Roush, 2002; Timmons et al., 1995; Treu \& Emberlin, 2000). The percentage of crosspollination by insects or wind depends on climatic conditions as well as the abundance of foraging bees (Hayter \& Cresswell, 2006). Experimental studies showed that rape pollen not only becomes airborne through wind but also through insect activity (Pierre, Vaissiere, Vallee, \& Renard, 2010).

Naturally, the risk of dispersing novel traits by pollen-mediated gene flow to neighboring plants and/or the environment is not restricted to GM crops. Plants with novel traits, being developed by classical plant-breeding techniques being per legal definition in the EU 'conventional' are being introduced to the European market. For example, imidazolinone-resistant winter oilseed rape was introduced into the European market and oilseed rape with tolerance to sulfonylurea herbicides developed by the "new plant breeding technique" Rapid Trait Development System (RTDS) was approved for cultivation in the USA and Canada as non-GM variety. The cultivation of these herbicide-resistant oilseed rape varieties may entail the same problems as often mentioned in a bulk of literature for GM herbicide-resistant oilseed rape, i.e. the occurrence of herbicide-resistant volunteer oilseed rape in the successive crop generations, spread of the herbicide-resistance trait by pollen-mediated gene flow to other production sites, as well as development of herbicide-resistant weeds (Huang, Gruber, \& Claupein, 2016; Munier, Brittan, \& Lanini, 2012; Warwick, Légère, Simard, \& James, 2008). So far, the cultivation of these plants is not regulated in the EU, i.e. no specific coexistence or segregation measures have to be applied. However, the situation is different for example in Canada, where the release of plants with novel traits into the environment is regulated by the Canadian Food Inspection Agency, irrespective of whether these traits have been introduced using biotechnology, mutagenesis, or conventional breeding techniques (Waltz, 2012). In consequence, the development of coexistence measures for novel trait-oilseed rape, be it GM or conventional, is still of particular importance for European agriculture. Coexistence measures proposed so far for oilseed rape crop production, include mainly isolation distances of a few to several thousands of meters (EC, 2009; Zhao et al., 2013) as well as a separate field edge harvest (Damgaard \& Kjellsson, 2005).

In the current study a high erucic acid oilseed rape (HEAR) variety was used as pollen donor and a low erucic acid oilseed rape (LEAR) variety was used as pollen recipient (Dietz-Pfeilstetter, Langhof, \& Rühl, 2013). This system was chosen because no herbicide resistant winter oilseed rape variety was available in Germany at the start of this study in 2010. Herbicide tolerant GM oilseed rape is not authorized for cultivation in the EU and non-GM herbicide resistant winter oilseed rape (Clearfield) was introduced in Germany as recently as 2012.The 
aim of the current three-year field study was (i) to analyze outcrossing frequencies between HEAR and LEAR winter oilseed rape fields, (ii) to evaluate whether varietal differences in the pollen donors (male sterility Lembke (MSL) hybrid vs. line variety) influence the amount of outcrossing, and (III) to assess the effect of discarding the first meters of the donor-facing recipient field edge in respect to securing coexistence between novel-trait and conventional oilseed rape.

\section{Method}

\subsection{Experimental Fields}

Field trials were established in 2010-2012 in the northern part of Germany at Mariensee. The experimental fields were located in a plain area with maximum $2 \mathrm{~m}$ difference in elevation between the highest and the lowest point. In each year, winter oilseed rape was sown at a density of 55-60 seeds per $\mathrm{m}^{2}$. A HEAR variety was used as pollen donor and a LEAR variety was used as pollen recipient. In each year, two experimental layouts were established, separated from each other by $80 \mathrm{~m}$ clover-grass. In one layout the HEAR line variety Maplus (Rapool-Ring GmbH, Isernhagen, Germany) was used as donor and the LEAR-variety Taurus (Rapool-Ring $\mathrm{GmbH}$, Isernhagen, Germany) was used as recipient. In the other layout the HEAR MSL (male sterility Lembke) hybrid variety Marcant (2012: Eraton, both varieties: Rapool-Ring GmbH, Isernhagen, Germany) was used as donor and the LEAR-variety Taurus as recipient. The size of both donor and recipient field was $75 \times 100 \mathrm{~m}$, respectively. In both layouts, HEAR donor and LEAR recipient fields were separated from each other by $20 \mathrm{~m}$ clover-grass. The donor fields were planted to the west of the recipient fields, i.e. in relation to the direction of the prevailing wind the recipient fields were established downwind from the donor fields to create a worst-case scenario. No HEAR cultivars had been grown previously on these plots. Crops were cultivated according to regional recommendations.

In each experimental year, oilseed rape was seeded by the first week of September, flowering of HEAR and LEAR plants occurred simultaneously approximately between 24 April and 21 May. Precipitation was measured at the experimental site with a Hellmann-type rain gauge (Fuess Meteorologische Instrumente KG, Königs Wusterhausen, Germany). Further meteorological data were received from the closest weather station operated by the German National Meteorological Service (DWD) at Wunstorf, approximately $10 \mathrm{~km}$ south of the experimental fields.

\subsection{Sampling and Analysis of the Percentage Erucic Acid in Oilseed Rape Seeds}

From each LEAR recipient field one sample of $250 \mathrm{~g}$ each was taken directly from the "harvest stream" of each of 150 sub plots (Figure 1). Each sub plot was $2 \mathrm{~m}$ wide and 2 to $6 \mathrm{~m}$ long, resulting in sub plot sizes of 4,8 or $12 \mathrm{~m}^{2}$. Sub plot sizes depended on their relative position to the HEAR donor field edge, with the small sub plots being located in the donor facing recipient field parts and the large sub plots at the far side of recipient fields (Figure 1). The distances of the sub plot center to the donor-facing recipient field edge were 1, 5, 9, 14, 20, 26, $33,41,49,57,65,73,81,89$, and $97 \mathrm{~m}$. Sub plots were $5 \mathrm{~m}$ apart from each other as well as from the parallel field border (Figure 1). In each year, harvesting was done in July with a Hege 180 plot combine (Wintersteiger AG, Ried, Austria). In 2012, the rearward $25 \mathrm{~m}$ of the LEAR MSL recipient field were not harvested because of delayed ripening in this part of the field.

Seed samples were cleaned using a grain cleaner (Damas A/S, Faaborg, Denmark) and stored within labeled paper bags in a seed storage room $\left(18{ }^{\circ} \mathrm{C}, 30 \%\right.$ relative humidity) until gas chromatography (GC) analysis.

The erucic acid content of each sample was determined by GC (data shown in supplemental Table 1). The method has been published in detail in Dietz-Pfeilstetter, Langhof, and Rühl (2013). The erucic acid content in seeds of the LEAR variety Taurus was tested on 20 bulk samples of 50 seeds to quantify the possible contamination with HEAR seeds and to allow for baseline correction. 


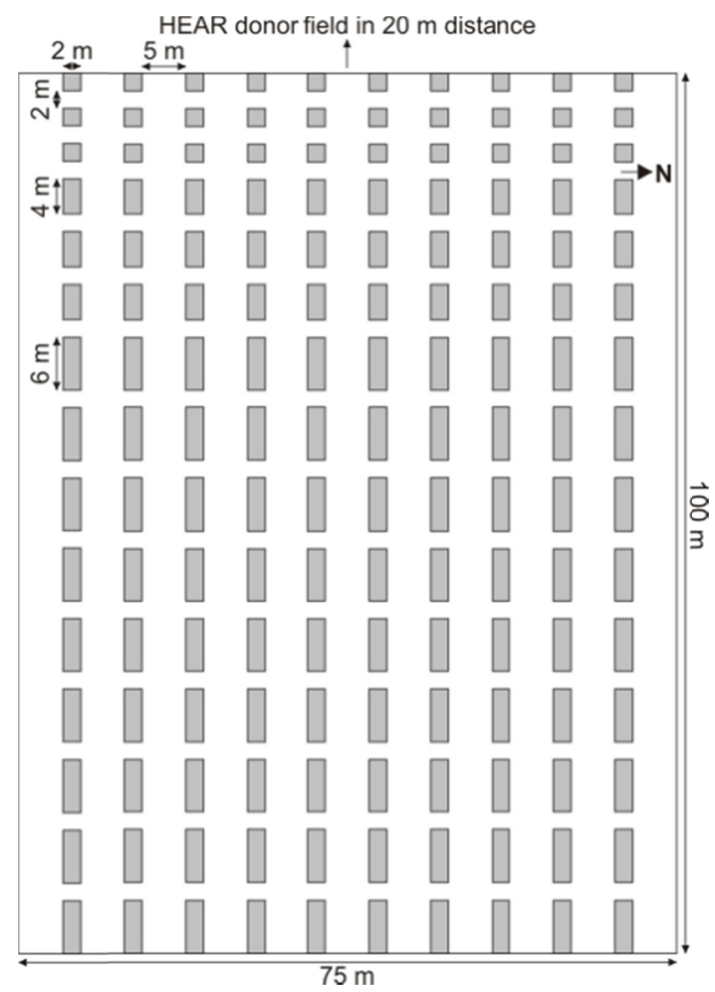

Figure 1. Arrangement of sub plots in the LEAR recipient fields (to scale)

\subsection{Data Analysis}

\subsubsection{Calculation of Outcrossing Rates}

The measured erucic acid content of each sample is not identical to percent outcrossing. Thus, to correlate erucic acid contents measured in seed samples from the recipient plot with percent $\mathrm{F} 1$ hybrid seeds (i.e. outcrossing rate) in seed samples, the F1 (filial 1) value was determined by GC measurements of individual seeds taken from the LEAR recipient samples. For this analysis a total of at least 500 individual seeds each of the Maplus, Marcant and Eraton-facing field edge of the respective recipient fields were subjected to GC analysis. The F1 HEAR $\times$ LEAR hybrid seeds were identified by elevated erucic acid contents between 25 and $35 \%$ (Cullen et al., 2008; Dietz-Pfeilstetter et al., 2013). The mean erucic acid content of single LEAR $\times$ HEAR F1 hybrid seeds was 33.6\% (3.08 SD) (Maplus $\times$ Taurus), 34.5\% (1.41 SD) (Marcant $\times$ Taurus) and 33.7\% (5.46 SD) (Eraton $\times$ Taurus). The mean erucic acid content of the recipient variety Taurus was $0.11 \%(0.17 \mathrm{SD})$. Of the 20 bulk samples tested, 13 were erucic acid-free and 7 contained erucic acid levels between 0.13 and $0.51 \%$. Accordingly, an erucic acid percentage of $0.11 \%$ corresponds to $0 \%$ outcrossing. The erucic acid content of each seed sample was converted to percentage outcrossing by assuming a linear relationship $y=m x+b$ with $y$ being the erucic acid content of seed sample, $m$ the mean erucic acid content of $F 1$ hybrid seeds, and $b$ the mean erucic acid content of the LEAR seed lots (Dietz-Pfeilstetter et al., 2013). For example, one Taurus $\times$ Marcant F1 hybrid seed in a sample of 200 seeds is equivalent to $0.5 \%$ outcrossing; this corresponds to an erucic acid content of this sample of $0.28 \%(0.17 \%+0.11 \%)$.

Using the nearest-neighbor method the outcrossing rates (i.e. percentage of F1 hybrid seeds) in the total harvest of the recipient fields, as well as selected parts of the recipient field, were calculated based on outcrossing rates detected in the sub plot samples. The nearest neighbor method assigns the value of the nearest point to each interpolated point. Calculation was done with the program Surfer version 8.00 (Golden Software Inc., 2002).

\subsubsection{Statistical Analysis}

Rayleigh's test was used to determine whether there was a predominant wind direction during the oilseed rape flowering period or if wind direction was random (Batschelet, 1981). Wind data were analyzed using the program Oriana 2.02 (Kovach Computing Services, 2007). Wind data recorded between 08:00 and 20:00 hours were considered, since this is approximately the period of both, pollinator activity and oilseed rape pollen release (McCartney \& Lacey, 1991; Williams, 1984). 
A linear model was fitted to test for the effect of field depth $(1,5,9,14,20,26,33,41,49,57,65,73,81$, 89, and $97 \mathrm{~m}$ ), donor variety (hybrid vs. line variety) and year $(2010,2011,2012)$ including all interaction terms on the outcrossing rates. Using the Box-Cox procedure an optimal transformation of the response variable (erucic acid content) to remediate deviations from the assumptions of the linear regression model was found. Then a full linear model was fitted and residuals were inspected. The optimal model was found using the R package MuMIn (Multi-Model Inference, Bartón, 2016); the model selection criteria was Akaike's information criteria (AIC) with small sample bias adjustment, AICc. The most parsimonious model was refitted with multiple linear regression, significance of model terms was assessed using Wald-type Test (Type III). Levels of each factor (i.e. field depth, year and donor variety) were compared with the Tukey HSD function using the R package multcomp (Hothorn et al., 2016).

Statistical analysis was carried out using RStudio (RStudio Team, 2015) and packages effects (Fox et al., 2016), MASS (Ripley et al., 2016), MuMIn (Bartón, 2016) and ggplot2 (Wickham \& Chang, 2016).

\section{Results}

\subsection{Weather Data during Rape Flowering}

Wind came on average from northwestern directions in 2010 and from southwestern directions in 2012, i.e. roughly from donor to recipient fields. In 2011 wind direction during the oilseed rape flowering period was variable, i.e. there was no mean wind direction $(\mathrm{p}>0.05)$. However, there was a 10 -days period with steady wind from the west (11-20 May 2011). In each year wind blew at an average speed of 3.4 to $4.4 \mathrm{~m} / \mathrm{s}$ (Beaufort scale 3, gentle breeze) during the flowering period. Mean daily temperature (mean of 24 hours) during flowering was 10.7 (2010), 14.1 (2011), and $13.6{ }^{\circ} \mathrm{C}$ (2012). Precipitation totaled 31.75 (2010), 21.5 (2011), and $36.5 \mathrm{~mm}$ (2012).

\subsection{Outcrossing Frequencies in Recipient Fields}

Overall, outcrossing frequencies of individual samples did not exceed $2.90 \%$, except for the line variety-variant in 2010 where one sample in the donor-facing recipient field edge had an elevated outcrossing rate of 5.19\% (Figure 2). Statistical analysis showed that the effect of field depth was significant ( $d f=14, F=13.94, p<$ 0.0001, Table 1). Multiple comparisons of means using the Tukey HSD function indicated that outcrossing frequencies at $1 \mathrm{~m}$ field depth were significantly highest compared to all other field depths sampled (Figure 2). A significant decrease in outcrossing was observed in the first donor-facing $20 \mathrm{~m}$ of recipient fields. In field depths $\geq 20 \mathrm{~m}$ no further significant decrease in outcrossing occurred (Figure 2). Thus, outcrossing was not restricted to the donor-facing recipient field parts but was observed in all parts of the fields, including the farthest distance into the field evaluated (i.e. $97 \mathrm{~m}$ ), where outcrossing rates varied between 0 and $2.7 \%$ (Figure 2). Detailed information on the spatial distribution of outcrossing rates in the recipient plots is available on the supplemental online archive.

Calculated outcrossing rates in the total harvest of the recipient fields were similar and ranged between 0.18 and $0.25 \%$, except for the recipient field bordering the HEAR MSL hybrid variety in 2010 with $0.09 \%$ outcrossing (Table 2). Thus, outcrossing rates were well below the EU labeling threshold of $0.9 \%$.

\subsection{Effect of Donor Variety Type}

There was a significant disordinal interaction between donor variety and year (Table 1). Using the criterion of non-overlapping confidence intervals for significance indicated that in 2010 and 2011, respectively, outcrossing between line and hybrid variety differed significantly, however, with higher rates in the line variety in 2010 and higher rates in the MSL variety in 2011. There was no significant difference between both varieties in 2012 (Figure 3).

\subsection{Discarding Field Edges}

The outcrossing rate in the total harvest of the recipient fields after discarding the first 3,6 or $12 \mathrm{~m}$ of the donor-facing recipient field border (corresponding to a reduction in total field size of 3, 6 and 12\%) is summarized in Table 2. Generally, discarding these first donor-facing meters reduced the total amount of outcrossing in the harvest. Mean reduction across years and variants was $10 \%, 14 \%$ and $18 \%$, in case of discarding the first 3,6, and $12 \mathrm{~m}$, respectively. However, discarding the first meters of the oilseed rape harvest sometimes had no (recipient field bordering the HEAR line variety in 2012) or only a marginal effect (recipient field bordering the HEAR MSL hybrid variety in 2010) on the total outcrossing rate (Table 2). 
Table 1. ANOVA table (degrees of freedom, F-values and level of significance) of a linear model testing the effects of field depth $(1,5,9,14,20,26,33,41,49,57,65,73,81,89$, and $97 \mathrm{~m})$, donor variety (MSL hybrid vs. line variety), year $(2010,2011,2012)$ and the interaction of donor variety * year on the outcrossing rate $(\%)(n=$ 866)

\begin{tabular}{llll}
\hline & DF & F-value & p-value \\
\hline (Intercept) & 1 & 83.98 & $<0.0001$ \\
Field depth & 14 & 13.94 & $<0.0001$ \\
Donor variety & 1 & 32.95 & $<0.0001$ \\
Year & 2 & 25.50 & $<0.0001$ \\
Donor variety * year & 2 & 24.29 & $<0.0001$ \\
\hline
\end{tabular}

Table 2. Mean outcrossing rates (\%) and standard deviations (SD) in the total harvest of the recipient fields ( $0 \mathrm{~m}$ discard width) and after discarding donor-facing field edges of 3, 6 and 12 m width in 2010 to 2012

\begin{tabular}{|c|c|c|c|c|c|c|}
\hline \multirow[b]{2}{*}{ Discard width } & \multicolumn{2}{|l|}{2010} & \multicolumn{2}{|l|}{2011} & \multicolumn{2}{|l|}{2012} \\
\hline & $\begin{array}{l}\text { Mean outcrossing } \\
(\%)\end{array}$ & SD & $\begin{array}{l}\text { Mean outcrossing } \\
(\%)\end{array}$ & $\mathrm{SD}$ & $\begin{array}{l}\text { Mean outcrossing } \\
(\%)\end{array}$ & $\mathrm{SD}$ \\
\hline \multicolumn{7}{|c|}{ Donor: HEAR line variety } \\
\hline $0 \mathrm{~m}$ & 0.25 & 0.52 & 0.18 & 0.35 & 0.20 & 0.47 \\
\hline $3 \mathrm{~m}$ & 0.21 & 0.40 & 0.16 & 0.27 & 0.20 & 0.47 \\
\hline $6 \mathrm{~m}$ & 0.19 & 0.34 & 0.15 & 0.24 & 0.20 & 0.48 \\
\hline $12 \mathrm{~m}$ & 0.17 & 0.34 & 0.15 & 0.25 & 0.20 & 0.48 \\
\hline \multicolumn{7}{|c|}{ Donor: HEAR MSL hybrid variety } \\
\hline $0 \mathrm{~m}$ & 0.09 & 0.23 & 0.25 & 0.35 & 0.20 & 0.39 \\
\hline $3 \mathrm{~m}$ & 0.08 & 0.22 & 0.23 & 0.31 & 0.18 & 0.38 \\
\hline $6 \mathrm{~m}$ & 0.08 & 0.22 & 0.21 & 0.28 & 0.17 & 0.38 \\
\hline $12 \mathrm{~m}$ & 0.08 & 0.22 & 0.19 & 0.27 & 0.15 & 0.38 \\
\hline
\end{tabular}

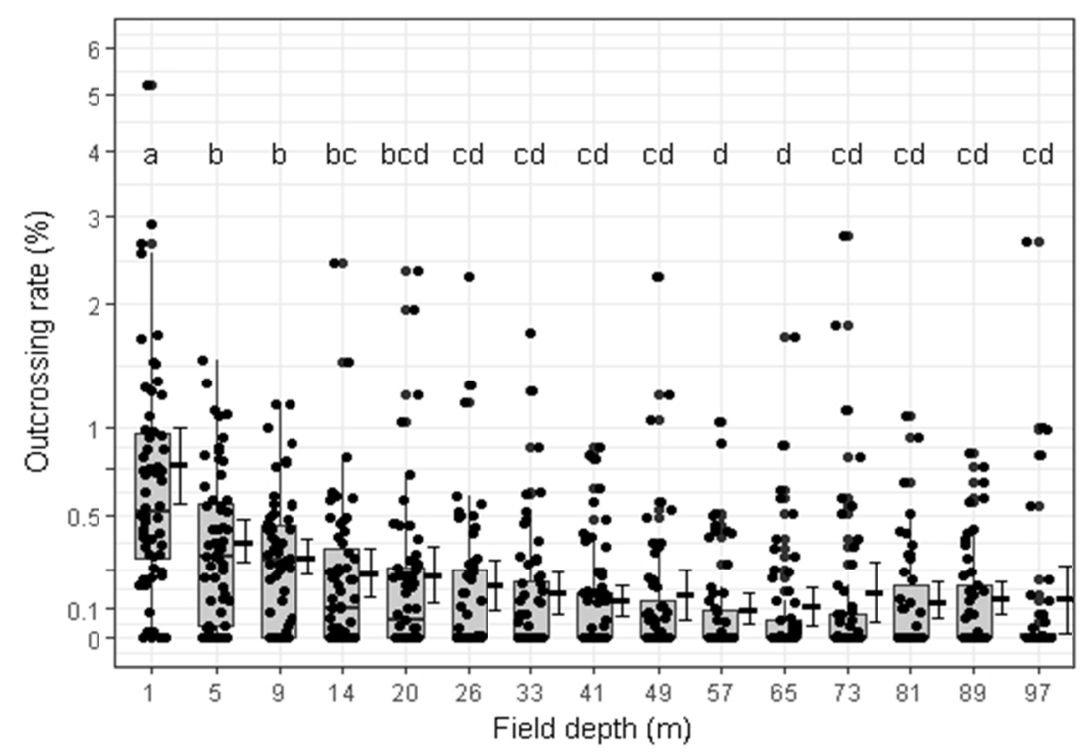

Figure 2. Boxplots with overlaid scatterplots showing outcrossing rates (percentage of F1-hybrid seeds) in relation to different recipient field depths. Black circles represent outcrossing rates of individual sub plots; to avoid overlap of data points with the same value, data points were 'jittered' horizontally. Error bars represent the mean $\pm 2 *$ standard error. Different letters above boxes indicate significant differences between outcrossing rates at different field depths 


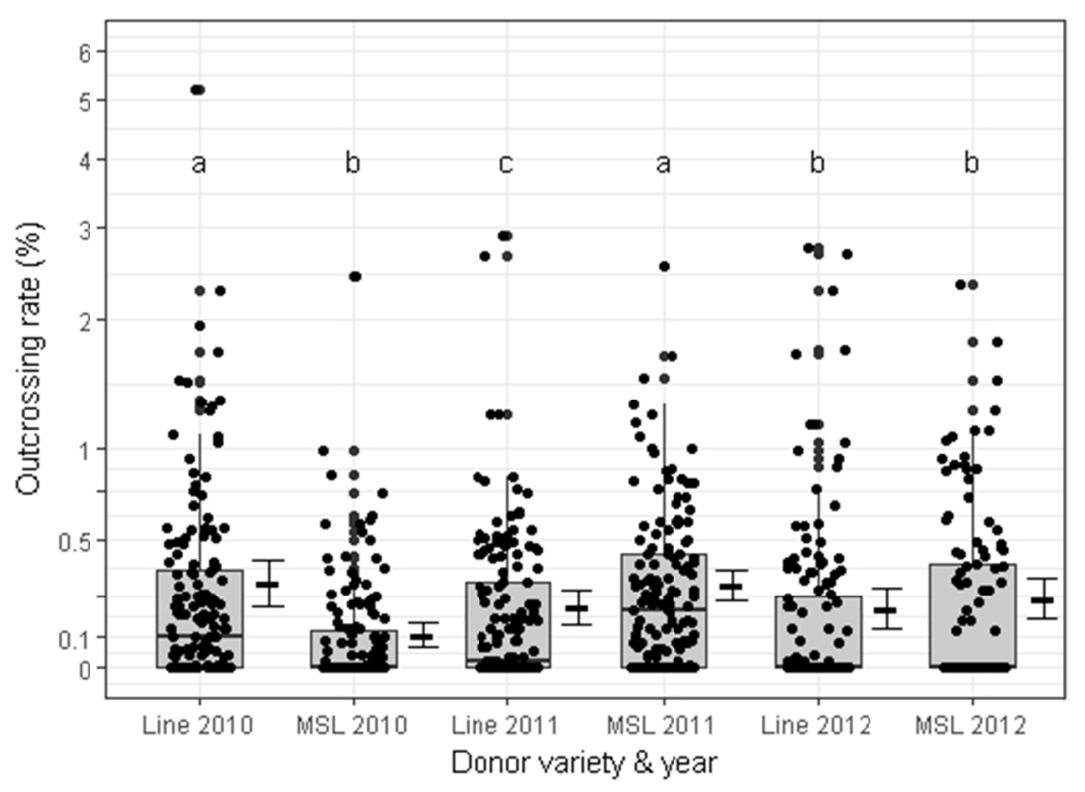

Figure 3. Boxplots with overlaid scatterplots showing outcrossing rates (percentage of F1-hybrid seeds) in relation to donor variety and year. Black circles represent outcrossing rates; to avoid overlap of data points with the same value, data points were 'jittered' horizontally. Error bars represent the mean $\pm 2 *$ standard error. Different letters above boxes indicate significant differences between outcrossing rates in dependence on donor variety and year

\section{Discussion}

\subsection{Outcrossing Frequencies in Oilseed Rape}

As expected and supported by previous studies (e.g. Hüsken \& Dietz-Pfeilstetter, 2007; Zhao et al., 2013), outcrossing rates in the current study were significantly highest in the donor-facing field edges of the recipient fields and decreased with distance into the field. This pattern of outcrossing suggests that wind is of importance for oilseed rape pollen-mediated gene flow over short distances. Earlier research has shown that airborne rape pollen concentrations decrease rapidly with increasing distance from the source field, with the majority of pollen travelling less than $20 \mathrm{~m}$ (Bilsborrow et al., 1998; Funk, 2006; Lavigne et al., 1998). However, larger dispersal distances in the range of a few kilometers have also been reported (Rieger et al., 2002; Timmons et al., 1995; Treu \& Emberlin, 2000). Several experimental studies found indications for wind-mediated short distance dispersal of oilseed rape pollen. Mesquida and Renard (1982) studied the importance of wind-pollination in oilseed rape using insect pollinator exclusion experiments. They found that wind was responsible for $23-29 \%$ of seed set at a distance of $\leq 6 \mathrm{~m}$, but just for $1-4 \%$ at a distance of more than $24 \mathrm{~m}$. In a gene flow study between Imidazolinone-resistant and susceptible oilseed rape with the pollen donor being planted in the center of the recipient field as well as donor and recipient being separated by a $2 \mathrm{~m}$ wide gap, a correlation between outcrossing frequency and wind direction was found in one of two study years (Krato \& Petersen, 2012). Higher outcrossing of transgenic oilseed rape in the direction of the prevailing wind was also shown by Lavigne et al. (1998). However, it is still a matter of debate whether pollen-mediated gene flow in oilseed rape is mainly caused by insects or by wind. Cresswell et al. (2004) assumed that the low density of airborne pollen in greater distance from the emitter, the pollen characteristics as well as the ineffectiveness of oilseed rape flowers in capturing airborne pollen makes long distance pollen-mediated gene flow by wind unlikely. On the other hand, full pollination seems to be possible irrespective of pollinator presence (Hoyle, Hayter, \& Cresswell, 2007). Wind pollination is gaining in importance when insect pollinator densities are low. Hayter and Cresswell (2006) studied the influence of insect abundance on pollination of oilseed rape fields flowering in spring vs. flowering in summer in England. In spring, when insect pollinator abundance was low, flowers were adequately pollinated after 5 days with just $10 \%$ of flowers being visited by bees. In contrast, summer-blooming flowers were visited by three bees per hour and were fully pollinated within 3 hours.

In the current study, although outcrossing decreased with distance into the recipient field, outcrossing events were detected in all field depths, including the farthest field depth investigated $(97 \mathrm{~m})$. In 2012 maximum 
percentages of F1 hybrid seeds (HEAR line variety $\times$ LEAR variety) were detected in the center as well as at the far side of the recipient field. Unexpected high outcrossing percentages at the rear field edge as well as irregular patterns of outcrossing are an indication of insect-mediated gene flow. This arguing is corroborated by earlier field studies that found random distribution of outcrossing events that could not be ascribed to wind direction during rape flowering (Bilsborrow et al., 1998; Funk, 2006; Rieger et al., 2002). Obviously, the combination of different pollinating agents (wind, various insects, direct contact, self-pollination) contribute to randomness of pollination events in oilseed rape (Rieger et al., 2002).

\subsection{Occurrence of F2 and Backcross Plants from F1 Volunteer Seeds}

The GC measurements on single seeds taken from the donor-facing recipient field edge in 2012 showed three seeds with erucic acid contents of about $58 \%$ as well as one seed with an erucic acid content of $14 \%$ (data not shown). Since the study was repeated at the same site in three successive years, these seeds could originate from F2-hybrids $(\mathrm{F} 1 \times \mathrm{F} 1)$, BC (backcross) $1(\mathrm{~F} 1 \times$ LEAR) or BC $2(\mathrm{~F} 1 \times$ HEAR) plants. Pandey, Kabdal, and Tripathi (2013) studied the inheritance of erucic acid in the closely genetically related species brown mustard (Brassica juncea (L.) Czern \& Coss). They crossed a LEAR with a HEAR cultivar; the erucic acid content of F1-seeds was intermediate between the parents, while the erucic acid content of F2-seeds segregated into 5 classes $(<2 \%, 10-22 \%, 22-34 \%, 34-46 \%$ and $>46 \%)$ with a ratio of $1: 4: 6: 4: 1$, that of $\mathrm{BC} 1$ into 3 classes $(<2 \%$, $10-22 \%, 22-34 \%$, ratio $1: 2: 1)$ and that of BC 2 also into 3 classes $(22-34 \%, 34-46 \%$ and $>46 \%$, ratio $1: 2: 1)$. Since oilseed rape volunteers in oilseed rape crops are a common phenomenon (Lutman, 1993) the occurrence of F1-volunteer plants in recipient fields in 2011 or 2012 cannot be excluded. However, the percentage of possible F1-volunteers might have been very low because 1), tillage after harvest of the oilseed rape crop reduced survival of oilseed rape seeds in the soil, 2), the overall percentage of F1-hybrid plants was relatively low in comparison with LEAR plants and 3), no accumulation of outcrossing rates was detected over the three experimental years. Moreover, as shown by Gruber and Claupein (2007) the seed productivity of oilseed rape volunteers is just $45 \%$ of that reached by the sown oilseed rape plants. Volunteers often show reduced growth due to competition and unfavorable germination. Thus, the impact of plants arising from F1 volunteer seeds on the results of the current study is considered to be very low.

\subsection{Difference MSL Hybrid Variety vs. Line Variety}

The interaction between donor variety and year was significant and disordinal, that means main effects cannot be sensibly interpreted. In 2010 outcrossing from the line variety was significantly higher, whereas in 2011 it was significantly lower than that from the MSL hybrid. In 2012 there was no significant difference between both varieties. In the present study, two different HEAR-donor varieties were used that are reported to differ in several properties. MSL hybrids are predominantly self-pollinating, with pollen being heavier than that of line varieties (Rapool, 2015). Moreover, in variety trials MSL hybrids produced about 25 to $35 \%$ more dry mass as well as 10 to $15 \%$ more flowers and thus a greater amount of pods than line varieties (Rapool, 2000). Possible varietal differences that might influence the outcrossing frequencies of oilseed rape are pollen quantity produced, the flowering time, or the selfing rate (Dietz-Pfeilstetter \& Zwerger, 2004; Reboud, 2003; Rieger et al., 2002). MSL hybrids and line varieties produce comparable amounts of pollen and nectar, i.e. both are regarded as efficient sources of pollen and nectar for honeybees (von der Ohe \& von der Ohe, 2000). Concerning the flowering time, no differences between the hybrid and the line varieties were found in the current study; the selfing rate and pollen weight was not analyzed in the current work. Moreover, although separated by $80 \mathrm{~m}$ clover-grass, outcrossing might have occurred across variants. As shown in literature, insects from different families can carry oilseed rape pollen across several landscape elements and have the potential to contribute to seed set (Chifflet et al., 2011).

Thus, in which way the amount of outcrossing was influenced by varietal differences in the pollen donors cannot be answered from results of the current work.

\subsection{Isolation Distance and Separate edge Harvest as Coexistence Measures of Novel-Trait Oilseed Rape}

With a maximum value of $0.25 \%$ in a three years' study outcrossing in the total harvest of recipient fields was always far below the $0.9 \%$ EU-labeling threshold for non-GM food and feed. Thus, results of the current study indicated that an isolation distance of $20 \mathrm{~m}$ between a single almost square-shaped 0.75 ha-GM and an equally-sized single non-GM oilseed rape field might be sufficient to ensure compliance with the threshold, even if further sources of contamination (e.g. seed impurities, volunteers) have to be considered. Several earlier studies on outcrossing in oilseed rape corroborate this finding (e.g. Damgaard \& Kjellsson, 2005; Hüsken \& Dietz-Pfeilstetter, 2007). However, in agricultural practice several GM and non-GM fields have to coexist in an agricultural landscape, increasing the risk of pollen-mediated gene flow from GM to non-GM fields. Thus, 
regulated isolation distances between GM and non-GM oilseed rape fields in some countries are very large, reaching 1,000 m (e.g. Zhao et al., 2013) or even 4,000 m (e.g. Lithuania and Latvia, EC, 2009). Particularly in small structured agricultural areas with multiple GM oilseed rape fields it might be necessary to spatially cluster non-GM and GM rape cultivation to achieve coexistence.

In the current study variable patterns of outcrossing were detected within recipient fields, with maximum values not being restricted to the pollen source facing field edge. This might be an indication for different agents of pollination (insects and wind). Under these circumstances, separate edge harvest has just a small effect on the GM content of the total field's harvest and is not as effective as for example in nearly exclusively wind pollinated crop species such as maize, where a considerable amount of outcrossing is found in the first few meters of the donor-facing field edge (e.g. Langhof et al., 2010). Although their study showed that a $5 \mathrm{~m}$ wide buffer zone surrounding the non-GM oilseed rape field can reduce outcrossing by about a third, Damgaard and Kjellsson (2005) concluded that isolation distances more effectively reduce pollen-mediated gene flow in oilseed rape than the use of a buffer zone, especially for small recipient fields. Concerning the structure of isolation distances, Morris (1994) remarked that vegetation-free zones might be relatively ineffective for distance isolation since no "dilution" of insect pollen loads can occur during flower visits.

\section{Conclusion}

Results of the current study indicate that an isolation distance of $20 \mathrm{~m}$ between a single almost square-shaped 0.75 ha-GM and an equally-sized single non-GM oilseed rape field might be sufficient to ensure compliance with the $0.9 \%$ EU-labeling threshold for non-GM food and feed. Discarding donor-facing field edges only marginally reduced outcrossing rates in the total harvest in the recipient fields, since outcrossing events could be detected in all recipient field depths. Due to a disordinal interaction between donor variety (MSL hybrid vs. line variety) and year $(2010,2011$, and 2012), the effect of the donor variety on outcrossing cannot be sensibly interpreted.

\section{References}

Allnutt, T., Blackburn, J., Copeland, J., Dennis, C., Dixon, J., Laybourn, R., ... Henry, C. (2013). Estimates of genetically modified oilseed in shared farming machinery. Annals of Applied Biology, 162, 119-130. https://doi.org/10.1111/aab.12007

Bartón, K. (2016). Package 'MuMIn'. Multi-model inference. Retrieved from http://mumin.r-forge.r-project.org/ MuMIn-manual.pdf

Batschelet, E. (1981). Circular statistics in biology. Academic Press, New York.

Becker, H. C., Damgaard, C., \& Karlsson, B. (1992). Environmental variation for outcrossing rate in rapeseed (Brassica napus L.). Theoretical and Applied Genetics, 84, 303-306. https://doi.org/10.1007/BF00229487

Beckie, H. J., \& Hall, L. M. (2015). The biological and agronomic (non) sense of ex-ante coexistence measures. Crop Science, 55, 2215-2224. https://doi.org/10.2135/cropsci2015.02.0105

Bilsborrow, P. E., Evans, E. J., Bowman, J., \& Bland, B. F. (1998). Contamination of edible double-low oilseed rape crops via pollen transfer from high erucic cultivars. Journal of the Science of Food and Agriculture, 76, 17-22. https://doi.org/10.1002/(SICI)1097-0010(199801)76:1<17::AID-JSFA903>3.0.CO;2-9

BMEL. (2014). Fragen und Antworten zu E10. Retrieved from http://www.bmel.de/DE/Landwirtschaft/ Nachwachsende-Rohstoffe/Bioenergie/e10/FAQ_node.html

Chifflet, R., Klein, E. K., Lavigne, C., Le Feon, V., Ricroch, A. E., Lecomte, J., \& Vaissiere, B. E. (2011). Spatial scale of insect-mediated pollen dispersal in oilseed rape in an open agricultural landscape. Journal of Applied Ecology, 48, 689-696. https://doi.org/10.1111/j.1365-2664.2010.01904.x

Collier, M. J., \& Mullins, E. (2012). Assessing the impact of pollen-mediated gene flow from GM herbicide tolerant Brassica napus into common wild relatives in Ireland. Biology and Environment, 112B, 257-266. https://doi.org/10.3318/BIOE.2012.12

Cresswell, J. E., Davies, T. W., Patrick, M. A., Russell, F., Pennel, C., Vicot, M., \& Lahoubi, M. (2004). Aerodynamics of wind pollination in a zoophilous flower, Brassica napus. Functional Ecology, 18, 861-866. https://doi.org/ 10.1111/j.0269-8463.2004.00917.x

Cullen, D., Squire, G. R., McNicol, J. W., Jacobs, J. H., Osborne, J. L., Ford, L., ...Young, M. W. (2008). Development and validation of gas chromatography and real-time quantitative PCR for the quantification of 
landscape-scale gene flow from varieties of high erucic acid (HEAR) oilseed rape. Journal of the Science of Food and Agriculture, 88, 2253-2264. https://doi.org/10.1002/jsfa.3340

Damgaard, C., \& Kjellsson, G. (2005). Gene flow of oilseed rape (Brassica napus) according to isolation distance and buffer zone. Agriculture, Ecosystems \& Environment, 108, 291-301. https://doi.org/10.1016/ j.agee.2005.01.007

Dietz-Pfeilstetter, A., \& Zwerger, P. (2004). Dispersal of herbicide resistance genes during the large scale cultivation of different transgenic herbicide resistant oilseed rape varieties. Zeitschrift für Pflanzenkrnakheiten und Pflanzenschutz (Special Edition), XIX, 831-838.

Dietz-Pfeilstetter, A., Langhof, M., \& Rühl, G. (2013). Outcrossing frequencies from multiple high erucic acid oilseed rape fields to a central receptor field. Euphytica, 191, 1-7. https://doi.org/10.1007/s10681012-0744-7

EC. (2003). Regulation (EC) No 1830/2003 of the European Parliament and of the Council of 22 September 2003 concerning the traceability and labelling of genetically modified organisms and the traceability of food and feed products produced from genetically modified organisms and amending Directive 2001/18/EC. Official Journal of the European Union L (Legislation), 268, 24-28. Retrieved from http://eur-lex.europa.eu/LexUriServ/LexUriServ.do?uri=OJ:L:2003:268:0024:0028:EN:PDF

EC. (2009). Commission staff working document accompanying report from the commission to the council and the European Parliament on the coexistence of genetically modified crops with conventional and organic farming-Implementation of national measures on the coexistence of GM crops with conventional and organic farming. Commission of the European Communities SEC (2009) 408 final. Retrieved from http://ec.europa.eu/agriculture/gmo/coexistence/sec313_en.pdf

Eurostat. (2017). Crop statistics. Retrieved from http://ec.europa.eu/eurostat/data/database.

FAOSTAT. (2016). Food and Agriculture Organization of the United Nations-Crop statistics. Retrieved from http://www.fao.org/faostat/en/\#data/QC

Fox, J., Weisberg, S., Friendly, M., Hong, J., Andersen, R., Firth, D., \& Taylor, S. (2016). Package 'effects'. Effect displays for linear, generalized linear, and other models. Retrieved from https://cran.r-project.org/ web/packages/effects/effects.pdf

Funk, T., Wenzel, G., \& Schwarz, G. (2006). Outcrossing frequencies and distribution of transgenic oilseed rape (Brassica napus L.) in the nearest neighbourhood. European Journal of Agronomy, 24, 26-34. https://doi.org/10.1016/j.eja.2005.04.002

Golden Software. (2002). Surfer, version 8. User's guide. Golden Software Inc., Golden, CO.

Gruber, S., \& Claupein, W. (2007). Fecundity of volunteer oilseed rape and estimation of potential gene dispersal by a practice-related model. Agriculture, Ecosyssytems \& Environment, 119, 401-408. https://doi.org/10.1016/j.agee.2006.08.007

Hayter, K. E., \& Cresswell, J. E. (2006). The influence of pollinator abundance on the dynamics and efficiency of pollination in agricultural Brassica napus: implications for landscape-scale gene dispersal. Journal of Applied Ecology, 43, 1196-1202. https://doi.org/10.1111/j.1365-2664.2006.01219.x

Hothorn, T., Bretz, F., Westfall, P., Heiberger, R. M., Schuetzenmeister, A., \& Scheibe, S. (2016). Package 'multcomp'. Retrieved from https://cran.r-project.org/web/packages/multcomp/multcomp.pdf

Hoyle, M., Hayter, K., \& Cresswell, J. E. (2007). Effect of pollinator abundance on self-fertilization and gene flow: Application to GM Canola. Biological Applications, 17, 2123-2135. https://doi.org/10.1890/ 06-1972.1

Huang, S., Gruber, S., \& Claupein, W. (2016). Field history of imidazolinone-tolerant oilseed rape (Brassica napus) volunteers in following crops under six long-term tillage systems. Field Crops Research, 185, 51-58. https://doi.org/10.1016/j.fcr.2015.10.019

Hüsken, A., \& Dietz-Pfeilstetter, A. (2007). Pollen-mediated intraspecific gene flow from herbicide resistant oilseed rape (Brassica napus L.). Transgenic Research, 16, 557-569. https://doi.org/10.1007/ s11248-007-9078-y

James, C. (2015). Global Status of Commercialized Biotech/GM Crops: 2015. ISAAA Brief No. 51. ISAAA: Ithaca, NY. 
Knispel, A. L., \& McLachlan, S. M. (2010). Landscape-scale distribution and persistence of genetically modified oilseed rape (Brassica napus) in Manitoba, Canada. Environmental Science and Pollution Research, 17, 13-25. https://doi.org/10.1007/s11356-009-0219-0

Kovach Computing Services. (2007). Oriana software, version 2.02. Kovach Computing Services, Anglesey, UK.

Krato, C., \& Petersen, J. (2012). Gene flow between imidazolinone-tolerant and -susceptible winter oilseed rape varieties. Weed Research, 52, 187-196. https://doi.org/10.1111/j.1365-3180.2012.00907.x

Langhof, M., Hommel, B., Hüsken, A., Njontie, C., Schiemann, J., Wehling, P., ... \& Rühl, G. (2010). Coexistence in maize: Isolation distance in dependence on conventional maize field depth and separate edge harvest. Crop Science, 50, 1496-1508. https://doi.org/10.2135/cropsci2009.11.0641

Lavigne, C., Klein, E. K., Vallee, P., Pierre, J., Godelle, B., \& Renard, M. (1998). A pollen-dispersal experiment with transgenic oilseed rape. Estimation of the average pollen dispersal of an individual plant within a field. Theoretical and Applied Genetics, 96, 886-896. https://doi.org/10.1007/s001220050816

Lutman, P. J. W. (1993). The occurrence and persistence of volunteer oilseed rape (Brassica napus). Aspects of Applied Biology, 35, 29-35.

McCartney, H. A., \& Lacey, M. E. (1991). Wind dispersal of pollen from crops of oilseed rape (Brassica napus L.). Journal of Aerosol Science, 22, 467-477. https://doi.org/10.1016/0021-8502(91)90005-3

Mesa, L. A., Howlett, B. G., Grant, J. E., \& Didham, R. K. (2013). Changes in the relative abundance and movement of insect pollinators during the flowering cycle of Brassica rapa crops: Implications for gene flow. Journal of Insect Science, 13, Article 13, 1-18. https://doi.org/10.1673/031.013.1301

Mesquida, J., \& Renard, M. (1982). Study of the pollen dispersal be wind and of the importance of wind-pollination in rapeseed (Brassica napus var. oleifera Metzger). Apidologie, 13(4), 353-366. https://doi.org/10.1051/apido:19820403

Morris, W. F., Kareiva, P. M., \& Raymer, P. L. (1994). Do barren zones and pollen traps reduce gene escape from transgenic crops? Ecological Applications, 4, 157-165. https://doi.org/10.2307/1942125

Munier, D. J., Brittan, K. L., \& Lanini, W. T. (2012). Seed bank persistence of genetically modified canola in California. Environmental Science and Pollution Research, 19, 2281-2284. https://doi.org/10.1007/ s11356-011-0733-8

Pandey, S., Kabdal, M., \& Tripathi, M. K. ( 2013). Study of inheritance of erucic acid in Indian Mustard (Brassica juncea L. Czern \& Coss). Octa Journal of Biosciences, 1, 77-84.

Pierre, J., Vaissiere, B., Vallee, P., \& Renard, M. (2010). Efficiency of airborne pollen released by honeybee foraging on pollination in oilseed rape: A wind insect-assisted pollination. Apidologie, 41, $109-115$. https://doi.org/10.1051/apido/2009056

Ramsay, G., Thompson, C., \& Squire, G. (2003). Quantifying landscape-scale gene flow in oilseed rape. Final report of DEFRA project RG0216: An experimental and mathematical study of the local and regional scale movement of an oilseed rape transgene. Department for Environment, Food and Rural Affairs, London, UK. Retrieved from http://webarchive.nationalarchives.gov.uk/20081023141438/http:/www.defra.gov.uk/enviro nment/gm/research/epg-rg0216.htm

Rapool. (2000). MSL-Hybriden machen mehr Masse. Retrieved February 14, 2017, from http://www.rapool.de/ index.cfm/nav/64/article/61.html

Rapool. (2015). Reichlich Bienennahrung. Retrieved February 14, 2017, from http:/www.rapool.de/index.cfm/ nav/85/article/66.html

Reboud, X. (2003). Effect of a gap on gene flow between otherwise adjacent transgenic Brassica napus crops. Theoretical and Applied Genetics, 106, 1048-1058. https://doi.org/10.1007/s00122-002-1142-7

Rieger, M. A., Lamond, M., Preston, C., Powles, S. B., \& Roush, R. T. (2002). Pollen-mediated movement of herbicide resistance between commercial canola fields. Science, 296, 2386-2388. https://dx.doi.org/ $10.1126 /$ science. 1071682

Ripley, B., Venables, B., Bates, D. M., Hornik, K., Gebhardt, A., \& Firth, D. (2016). Package 'MASS'. Support functions and datasets for Venables and Ripley's MASS. Retrieved from https://cran.r-project.org/ web/packages/MASS/MASS.pdf 
RStudio Team. (2015). RStudio: Integrated Development for R. RStudio, Inc. Boston, MA, USA. Retrieved from http://www.rstudio.com

Timmons, A. M., O’Brien, E. T., Charters, Y. M., Dubbels, S. J., \& Wilkinson, M. J. (1995). Assessing the risks of wind pollination from fields of genetically modified Brassica napus ssp. Oleifera. Euphytica, 85, 417-423. https://dx.doi.org/10.1007/BF00023975

Treu, R., \& Emberlin, J. (2000). Pollen dispersal in the crops maize (Zea mays), oil seed rape (Brassica napus ssp. oleifera), potatoes (Solanum tuberosum), sugar beet (Beta vulgaris ssp. vulgaris) and wheat (Triticum aestivum). A report for the Soil Association from the National Pollen Research Unit, University College, Worcester, UK. Retrieved from http://ibrarian.net/navon/paper/Pollen_dispersal_in_the_crops_Maize_Zea _mays__O.pdf?paperid $=2943414$

Von der Ohe, W., \& von der Ohe, K. (2000). Raps: Keine Sortenunterschiede im Pollen-und Nektargehalt. Raps, 18(2), 92-93.

Waltz, E. (2012). Tiptoeing around transgenics. Nature Biotechnology, 30, 215-217. https://dx.doi.org/10.1038/ nbt. 2143

Warwick, S. I., Légère, A., Simard, M. J., \& James, T. (2008). Do escaped transgenes persist in nature? The case of an herbicide resistance transgene in a weedy Brassica rapa population. Molecular Ecology, 17, 1387-1395. https://dx.doi.org/10.1111/j.1365-294X.2007.03567.x

Wickham, H., \& Chang, W. (2016). Package 'ggplot2'. Create elegant data visualisations using the grammar of graphics. Retrieved from https://cran.r-project.org/package=ggplot2/ggplot2.pdf

Williams, I. H. (1984). The concentration of airborne rape pollen over a crop of oil-seed rape (Brassica napus L). Journal of Agricultural Science, 103, 353-357. https://doi.org/10.1017/S0021859600047316

Zhao, X. X., Tang, T., Chen, G. M., Liu, F. X., Wang, X. L., Bu, C. P., \& Lu, C. M. (2013). Rationalizing the isolation distance needed for field trials involving genetically modified rapeseed (Brassica napus L.) in China. Chinese Science Bulletin, 58(13), 1558-1567. https://dx.doi.org/10.1007/s11434-012-5595-z

\section{Copyrights}

Copyright for this article is retained by the author(s), with first publication rights granted to the journal.

This is an open-access article distributed under the terms and conditions of the Creative Commons Attribution license (http://creativecommons.org/licenses/by/4.0/). 